\begin{tabular}{|l|l|l||}
\hline \multicolumn{2}{|c|}{ PublisherInfo } \\
\hline \hline PublisherName & $:$ & BioMed Central \\
\hline \hline PublisherLocation & $:$ & London \\
\hline \hline PublisherImprintName & $:$ & BioMed Central \\
\hline \hline
\end{tabular}

\title{
Bite makes way for brain
}

\begin{tabular}{|l|c|l||}
\hline \multicolumn{2}{|c|}{ ArticleInfo } \\
\hline \hline ArticleID & $:$ & 4928 \\
\hline \hline ArticleDOI & $:$ & $10.1186 /$ gb-spotlight-20040326-01 \\
\hline \hline ArticleCitationID & $:$ & spotlight-20040326-01 \\
\hline \hline ArticleSequenceNumber & $:$ & 280 \\
\hline \hline ArticleCategory & $:$ & Research news \\
\hline ArticleFirstPage & $:$ & 1 \\
\hline \hline ArticleLastPage & $:$ & 4 \\
\hline \hline & & RegistrationDate : 2004-3-26 \\
\hline ArticleHistory & $:$ & OnlineDate \\
\hline \hline ArticleCopyright & $:$ & BioMed Central Ltd2004-3-26 \\
\hline \hline ArticleGrants & $:$ & \\
\hline \hline ArticleContext & $:$ & 130594411 \\
\hline \hline
\end{tabular}


A pile of evidence from disparate disciplines indicates that a single change in a single gene - MYHI6 may be responsible for significant morphologic differences between humans and other primates, including possibly the increase in brain size that set the earliest species of Homo apart from their kin. This is the first protein disparity between humans and chimps that can be correlated to drastic anatomical changes seen in the fossil record, according to a group of University of Pennsylvania researchers who published a letter in the March 25 issue of Nature.

"This is a brilliant piece of detective work that has enormous implications for medicine, biology, evolution, molecular genetics, [and] the human genome," said Frederick S Kaplan, a professor of orthopedic molecular medicine at Penn who was not part of the study. "By relegating a gene to the evolutionary garbage heap, we were able to lift the constraints to the development of human complexity," he told us.

Powerful muscles for biting practically dominate the cranial structures of most primates, including gorillas, chimps, and extinct Australopithecus and Paranthropus species. A gene responsible for a majority of jaw musculature was lost from human ancestors, presumably 2.4 million years ago, according to the study. Drastic reductions in these muscles may have lifted significant physical constraints on braincase volume, allowing primates with weak jaws and big brains to eventually think about their origins.

A research team headed by Hansell $\mathrm{H}$ Stedman unearthed a previously unannotated human gene, MYH16, using degenerate polymerase chain reaction. The gene encodes a myosin heavy chain protein or rather it would, if it didn't have a frameshift deletion at codon 660. But the group needed to make sure that the deletion was more than an artifact. So they looked and found that it was conserved in at least six geographically distinct human populations. Moreover, they found full-length orthologs in at least seven nonhuman primate species. Humans and macaques both transcribe mRNA from the gene, but apparently only in muscles of mastication. The experiments suggested that indeed this fixed mutation causes a proteomic difference between humans and other primates. At a press briefing in Philadelphia last Friday (March 19), Stedman called the find a 'slam dunk.'

Closer inspection of the anatomical structures affected by such a mutation revealed clues as to what such a change might have meant for human predecessors. Jaw muscle samples from both macaques and humans revealed that humans have a relative dearth of so-called fast twitch muscle. The hypertrophy of type II fibers, the authors write, actually resembles that seen in a rare limb-muscle myopathy also caused by a myosin gene mutation.

The comparatively colossal jaw muscles in apes certainly have evolutionary advantages in feeding. And they could impart other important survival traits, such as the ability to fatally bite a competing male, said Nancy Minugh-Purvis, coauthor on the paper and director of advanced gross anatomy at Penn.

Loss of such muscle mass would affect survival, and also development, as the forces muscles exert have been largely implicated in sculpting bone structure. Stedman cited, as an example, studies involving specific knockout mice, which have doubled muscle mass accompanied by altered bone 
structure. "This is built-in precedent for a causal relationship," Stedman said. Kaplan offered the effects on children afflicted with polio as an example. "They have normal genes, but they have abnormal muscle pull because the nerves to the muscles aren't working," he told us. "By deactivating the muscle, you can see dramatic effects on the skeleton."

In nonhuman primates, as in some other animals, attachment points for masticatory musculature particularly the temporalis muscle - run along a prominent sagittal ridge, a bony protuberance where plates of the skull are fused. At the briefing, the authors suggest that stress from the temporalis muscle could cause the suture - the spaces between brain plates that, in humans, remain flexible until adulthood - to fuse early in development.

"Very possibly, the massive muscles of mastication could have been constraining the brain by limiting the flexibility of growth plates in the skull," said Minugh-Purvis. For humans, the rather thin slivers of muscle running up the temples would have lifted constraints on brain size, such that the group jokingly named the mutation $R T F$ for "room for thought."

The change appears to correlate nicely with features in the fossil record. Australopithecus and Paranthropus appear to have had large masticatory muscles and small brain cases, whereas Homo species appearing 1.8 to 2.0 million years ago seem to have smaller musculature and increased cranial capacity. Alignment of $M Y H 16$ with orthologous vertebrate sequences reveals an approximate date for the human mutation at 2.4 million years ago. Since two million years ago, the human brain has essentially tripled in size, said Minugh-Purvis..

Cliff Tabin, professor of genetics at Harvard Medical School told us that this work may change some preconceptions about human evolution: "Even though in the fossil record you have a fairly abrupt transition... one might have expected that even if it's an instant in geologic time, it would be something that took place over tens of thousands of years through selective pressure." He added, "Potentially, this was quite a dramatic and sudden change." The situation, he noted, is fairly unique - hinging on the existence of a jaw-specific myosin as well as other myosins expressed in the jaw that could take up the slack for the lost human muscle.

The findings may open doors to developmental and disease studies. Kaplan said that studies have shownthat fibroblast growth factor receptors (FGFRs) control the regulation of bone morphogenetic protein (BMP) in fusing skull sutures. Such factors may be involved in craniosynostoses, diseases in which sutures fuse prematurely.

Kaplan said he will be collaborating with Stedman's group to investigate how changes in skull biomechanics due to musculature may alter the relation between BMPs, FGFRs, and the other players involved. And, of course, such research will likely lead to ponderings about how a slack-jawed, bigheaded primate may best compete for food and mates in a population presumably dominated by males with a tough bite.

The group is not the first to make such conjectures about the morphologic differences between human and ape. "In the adult male anthropomorphous ape, as Rutimeyer, and others, have insisted, it is precisely the effect which the jaw-muscles by their great development have produced on the skull that causes it to differ so greatly in many respects from that of man," Charles Darwin wrote in 1871. 
For some, however, the findings may be hard to swallow. "Even if it's a scientifically based just-so story, it's still a little bit of a just-so story... We can't really prove it, but I think there are enough morphological characters that changed in concert that could all be explained by this mutation that there really is a parsimony to it that is quite striking and makes it quite believable," Tabin said.

\section{References}

1. Nature, [http://www.nature.com]

2. Frederick S Kaplan, [http://www.uphs.upenn.edu/ortho/physicians/faculty/kaplan.html]

3. Hansell H Stedman, [http://www.uphs.upenn.edu/surgery/fac/hhs.html]

4. Regulation of skeletal muscle mass in mice by a new TGF-Beta superfamily member

5. Femoral morphology and cross-sectional geometry of adult myostatin-deficient mice

6. Early Human Phylogeny, [http://www.mnh.si.edu/anthro/humanorigins/ha/a_tree.html]

7. The BMP antagonist noggin regulates cranial suture fusion

8. Darwin C: Descent of Man, 1871:144., [http://www.infidels.org/library/historical/charles_darwin/ descent_of_man/index.shtml]

This PDF file was created after publication. 